\title{
INDICATORS OF INFLAMMATION IN THE PATHOGENESIS OF UNSTABLE ANGINA
}

D0I: 10.36740/WLek202003132

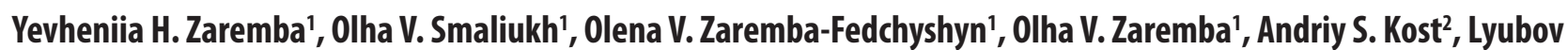 \\ Ye. Lapovets ${ }^{2}$, Zoriana V. Tomkiv ${ }^{3}$, Oksana M. Holyk ${ }^{1}$ \\ 'DEPARTMENT OF FAMILY MEDICINE FROM FACULTY OF POSTGRADUATE EDUCATION, DANYLO HALYTSKY NATIONAL MEDICAL UNIVERSITY, LVIV, UKRAINE \\ 2DEPARTMENT OF CLINICAL LABORATORY DIAGNOSTICS FROM FACULTY OF POSTGRADUATE EDUCATION, DANYLO HALYTSKY NATIONAL MEDICAL \\ UNIVERSITY, LVIV, UKRAINE \\ ${ }^{3}$ DEPARTMENT OF PEDIATRICS AND NEONATOLOGY FROM FACULTY OF POSTGRADUATE EDUCATION, DANYLO HALYTSKY NATIONAL MEDICAL \\ UNIVERSITY, LVIV, UKRAINE
}

\begin{abstract}
The aim: Research of blood lipid spectrum, level of anti-inflammatory cytokines and C-reactive protein of coronary heart disease patients.

Materials and methods: There was examined 61 patients with unstable angina, who had been on hospital care in the cardiology department of the Lviv National Emergency Hospital. Their average age was $68.3 \pm 1.9$ years. The control group included 20 generally healthy persons. There was estimated blood lipid spectrum, C-reactive protein, fibrinogen and proinflammatory cytokine of patients.

Results: There was determined considerable increase total cholesterol, low density lipoprotein cholesterol, very low density lipoprotein cholesterol, triglycerides and coefficient of atherogenicity. High level of C-reactive protein and pro-inflammatory cytokines were detected in patients with unstable angina.

Conclusions: In patients with unstable angina was revealed a significant increase of proinflammatory cytokines levels in the blood serum: interleukin-1 $\beta$, interleukin-6, interleukin-17, TNF-a and C-reactive protein, fibrinogen, which indicates activation of the inflammatory process. In patients with unstable angina was detected a significant disorder of blood lipid spectrum. For its correction should be recommended diet and hypolipidemic agents.
\end{abstract}

KEY WORDS: unstable angina, interleukins, C-reactive protein

Wiad Lek. 2020;73(3):569-573

\section{INTRODUCTION}

Cardiovascular disease is a leading cause of population disability and mortality worldwide, and angina is the most common symptom of cardiovascular disease $[1,2,3,4,5]$. At last count, approximately 9 million people in the United States have coronary heart disease [4]. For the last two decades, ischemic heart disease mortality in Poland increased in people under 65 [3]. Thus, cardiovascular disease is an important medical, biological and social problem as in Ukraine as in other countries of the world. That is why improving diagnostics and strategies for therapy is essential and priority $[3,5,6]$. Pathophysiological basis for the development of cardiovascular diseases, namely coronary heart disease (CHD) is coronary atherosclerosis. The morphological substrate of atherosclerosis is an atherosclerotic plaque, which prevents perfusion in the affected segment, contributes to reduction of coronary blood flow and leads to myocardial ischemia $[3,7]$.

Significantly increases risk of atherosclerosis at CHD in availability of related risk factors: hypertension, dyslipidemia, smoking, being male, old age, diabetes, increased heart rate, low physical activity, excess body weight, climatic and geographical factors and others. Nowadays, they number more than 200. Though, smoking 1.6 times more increases the risk of coronary complications, hypertension (systolic arterial vise greater than $195 \mathrm{mmHg}$ ) - 3 times, hypercholesterolemia ( $8.5 \mathrm{mmol} / 1,330 \mathrm{mg} / \mathrm{dcl}$ or more) -4 times, the set of three risk factors -16 times $[8,9]$.

Unstable angina (UA) constitutes acute coronary syndrome $[10,11]$. In unstable angina, the duration of ischemia is insufficient to cause myocardial necrosis. Based on current data, the trigger mechanism of the pathogenesis of unstable angina is damage to the atherosclerotic plaque with thrombosis and episodes of spasm with subsequent progression of stenosis. $[3,7,12,13,14]$. An atherosclerotic plaque is formed from an atheromatous (lipid) core and fibroids, which includes smooth muscle cells, collagen, proteoglycans, macrophages, lymphocytes [15]. When an unstable plaque is damaged, after the rupture or erosion of the atherosclerotic plaque, coagulation factors interact with the thrombogenic content of the plaque, specifically collagen, thrombosis are developing. If the balance between prothrombotic and fibrinolytic mechanisms is unfavorable - occlusive blood clots are formed in this section of the vessel crease, which cause acute coronary syndromes, specifically unstable angina. The plaque vulnerability depends on the location, size and 
Table I. Risk factors of coronary heart disease in patients with unstable angina

\begin{tabular}{|c|c|c|c|c|c|c|}
\hline \multirow[t]{2}{*}{ Risk factors } & \multicolumn{2}{|c|}{$\begin{array}{c}\text { Total patients with } \\
\text { UA }(n=61)\end{array}$} & \multicolumn{2}{|c|}{$\begin{array}{l}\text { Male } \\
(n=22)\end{array}$} & \multicolumn{2}{|c|}{$\begin{array}{c}\text { Female } \\
(n=39)\end{array}$} \\
\hline & абc. & $\%$ & абс. & $\%$ & абс. & $\%$ \\
\hline Age & 57 & 93,4 & 21 & 95,5 & 36 & 92,3 \\
\hline Heredity & 14 & 22,3 & 4 & 19,0 & 10 & 25,6 \\
\hline Arterial Hypertension & 57 & 93,4 & 20 & 90,9 & 37 & 94,9 \\
\hline Hypodynamia & 28 & 45,9 & 10 & 45,5 & 18 & 46,2 \\
\hline Overweight & 12 & 19,7 & 5 & 22,7 & 7 & 17,9 \\
\hline Impaired glucose tolerance & 12 & 19,7 & 3 & 13,6 & 9 & 23,1 \\
\hline Obesity & 17 & 27,9 & 3 & 13,6 & 14 & 35,9 \\
\hline Dyslipidemia & 49 & 80,3 & 18 & 81,8 & 31 & 79,5 \\
\hline Smoking & 16 & 26,2 & 15 & 68,2 & 1 & 2,3 \\
\hline Alcohol consumption & 5 & 8,2 & 4 & 18,2 & 1 & 2,3 \\
\hline Psycho-emotional factors & 21 & 34,4 & 7 & 31,8 & 14 & 35,9 \\
\hline Occupational hazards & 8 & 13,1 & 4 & 18,2 & 4 & 10,3 \\
\hline
\end{tabular}

Table II. Clinical characteristics of patients with unstable angina

\begin{tabular}{|c|c|c|c|c|c|c|}
\hline \multirow[t]{2}{*}{ Risk factors } & \multicolumn{2}{|c|}{$\begin{array}{c}\text { Total patients with } \\
\text { UA }(n=61)\end{array}$} & \multicolumn{2}{|c|}{$\begin{array}{l}\text { Male } \\
(n=22)\end{array}$} & \multicolumn{2}{|c|}{$\begin{array}{c}\text { Female } \\
(n=39)\end{array}$} \\
\hline & абc. & $\%$ & абс. & $\%$ & абс. & $\%$ \\
\hline \multicolumn{7}{|c|}{ Nature of pain } \\
\hline Clutching & 53 & 87,0 & 19 & 86,4 & 34 & 87,2 \\
\hline Scorching & 8 & 13,0 & 3 & 13,6 & 5 & 12,8 \\
\hline \multicolumn{7}{|c|}{ Localization of pain } \\
\hline Behind the sternum & 57 & 93,4 & 20 & 90,9 & 37 & 94,9 \\
\hline In the heart area & 4 & 6,6 & 2 & 9,1 & 2 & 5,1 \\
\hline Irradiation & 11 & 18,0 & 3 & 13,6 & 8 & 20,5 \\
\hline $\mathrm{SBP} \mathrm{mm} \mathrm{Hg}$ & 153,2 & - & 150,7 & - & 153,2 & - \\
\hline DBP mm Hg & 90,4 & - & 89,1 & - & 91,2 & - \\
\hline HR beats / min & 84,0 & - & 88,2 & - & 102,9 & - \\
\hline Irregular heartbeat & 21 & 31,8 & 10 & 45,5 & 11 & 28,2 \\
\hline Conduction abnormality & 4 & 6,6 & 3 & 13,6 & 1 & 2,6 \\
\hline Ejection fraction, \% & 61,3 & - & 60,5 & - & 61,8 & - \\
\hline
\end{tabular}

composition of the lipid nucleus, circular wall tension, the influence of blood flow on the surface of the atherosclerotic plaque (sher stress) $[10,11,14,15,16]$. If the balance is favorable, the blood clot is absorbed, at the site of the lesion there is a growth of connective tissue and calcification of the vascular wall, which, in turn, leads to deformation and stenosis of the vascular gap with consequential emergence of symptoms of stable angina. [16]. It should be noted that the process of destabilizing the fibrous coating of the plaque, especially its rupture, is accompanied by activation of local inflammation. Pathomorphological researches indicate the presence of a large number of inflammatory cells, T-lymphocytes, monocytic macrophages on the place of rapture or on the surface of plaque erosion $[9,13,17]$.

Endothelial dysfunction has a great role in the process of atherogenesis. It is an important cause of insufficient vasodilation and spasm of coronary arteries of different caliber [9].

To understand the processes that develop in an atherosclerotic altered vascular wall, it is important to study the markers of inflammation, since inflammatory processes play an important role in the formation and destabilization of atherosclerotic plaque. From inflammatory markers attract a much attention C-reactive protein (CRP), proinflammatory cytokines: interleukin-1 $\beta$ (IL-1 $\beta$ ) interleukin-6 (IL-6), interleukin-17 (IL-17), necrosis factor of alpha tumors (TNF-alpha) $[18,19,20,21]$.

\section{THE AIM}

Investigation of blood lipid spectrum, levels of proinflammatory cytokines and C-reactive protein, fibrinogen in patients with coronary heart disease. 
Table III. Indicators of blood lipid spectrum in patients with unstable angina and control group (M $\pm S D)$

\begin{tabular}{ccc}
\hline Indicators & $\begin{array}{c}\text { Patients with UA } \\
(\mathbf{n = 6 1 )}\end{array}$ & $\begin{array}{c}\text { Control group } \\
(\mathbf{n}=\mathbf{2 0})\end{array}$ \\
\hline Total $\mathrm{CS}, \mathrm{mmol} / \mathrm{I}$ & $6,02 \pm 1,14^{*}$ & $4,77 \pm 0,98$ \\
\hline $\mathrm{HDL}, \mathrm{mmol} / \mathrm{I}$ & $1,21 \pm 0,27$ & $1,33 \pm 0,48$ \\
\hline $\mathrm{TG}, \mathrm{mmol} / \mathrm{I}$ & $1,96 \pm 0,92^{*}$ & $1,30 \pm 0,44$ \\
\hline $\mathrm{LDL}, \mathrm{mmol} / \mathrm{I}$ & $3,91 \pm 0,96^{*}$ & $2,85 \pm 0,99$ \\
\hline $\mathrm{VLDL}, \mathrm{mmol} / \mathrm{I}$ & $0,89 \pm 0,42^{*}$ & $0,59 \pm 0,20$ \\
\hline $\mathrm{IA}$ & $3,95 \pm 1,45^{*}$ & $2,59 \pm 0,97$ \\
\hline
\end{tabular}

* - The credibility of the difference between the indicators of the control group $(p<0,01)$

Table IV. Indicators of inflammation in patients with unstable angina and control group ( $M \pm S D$ )

\begin{tabular}{ccc}
\hline Indicators & $\begin{array}{c}\text { Patients with UA } \\
\text { (n=61) }\end{array}$ & $\begin{array}{c}\text { Control group } \\
\text { (n=20) }\end{array}$ \\
\hline CRP $\mathrm{mg} / \mathrm{I}$ & $9,81 \pm 4,12^{*}$ & $3,92 \pm 1,55$ \\
\hline $\mathrm{IL}-1 \beta, \mathrm{pg} / \mathrm{ml}$ & $5,90 \pm 1,13^{*}$ & $3,20 \pm 0,87$ \\
\hline $\mathrm{IL}-6, \mathrm{pg} / \mathrm{ml}$ & $7,97 \pm 2,56^{*}$ & $4,04 \pm 1,66$ \\
\hline $\mathrm{IL}-17, \mathrm{pg} / \mathrm{ml}$ & $15,30 \pm 6,02^{*}$ & $8,66 \pm 3,11$ \\
\hline TNF-a, pg / ml & $1,58 \pm 0,76^{*}$ & $0,72 \pm 0,25$ \\
\hline Fibrinogen, g/I & $4,47 \pm 1,31^{*}$ & $2,86 \pm 0,84$ \\
\hline
\end{tabular}

* - The credibility of the difference between the indicators of the control group $(p<0,01)$

\section{MATERIALS AND METHODS}

There were examined 61 patients with acute ischemic heart disease, namely with unstable angina (UA), who were hospitalized in the cardiology department of the National Emergency Hospital in Lviv. Among the surveyed were 39 women (64\%) and 22 men (36\%), their average age was $68,3 \pm 1,9$ years. The diagnosis of the disease and therapeutic tactics were determined in accordance with the orders of the Ministry of Health of Ukraine, as well as in accordance with the recommendations of the European Society of Cardiologists and the American College of Cardiologists on the management of patients with unstable angina. Patients received standard drug treatment, which included anticoagulants, antiplatelet agents, statins, angiotensin-converting enzyme inhibitors, beta-blockers. To eliminate angina attacks, patients were prescribed nitrates. The study did not include patients with severe cardiac, hepatic, and renal failure, cancer, alcoholism, or drug addiction. The control group included 20 practically healthy individuals of age and gender. The study was approved by the local bioethics committee and conducted in accordance with the principles of the Declaration of Helsinki. The patients were given general clinical and instrumental examination methods, they were determined the indicators of proinflammatory cytokines (interleukin-1 $\beta$ (IL-1 $\beta$ ), interleukin-6 (IL-6), interleukin-17 (IL-17), necrosis factor of alpha tumors (TNF- $\alpha$ )) and C-reactive protein (CRP), fibrinogen. Examination of patients was performed on entry to the hospital.

The lipid spectrum of the blood was determined by an investigation in blood serum of total cholesterol of (STC), triglycerides (TG), high density lipoprotein cholesterol (HDLC) with using reagents from "Human" (Germany). The content of low density lipoprotein cholesterol (LDLC) was calculated using the Friedewald formula: LDLC $=$ STC - HDLC - (TGx0,45), where TGx0,45 - quantity of cholesterol in the composition of very low density lipoproteins (QCCVLDL). The coefficient of atherogenicity (CA) was calculated by the formula A.N. Klimov: IA = STC - QCCVLDL) / QCCVLDL.

Indicators of proinflammatory interleukins were determined in blood serum by enzyme-linked immunosorbent assay using "Vector BEST" test systems (Russia, Novosibirsk) for determination of the content of IL- $1 \beta$, IL- 6 , TNF- $\alpha$, "Cytokine" (Russia, St. Petersburg) - for determination of the IL-17 according to the instructions, which are attached to the reagent kits. Quantitative determination of C-reactive protein in blood serum was performed by immunoturbidimetric method on an automatic Cobas Integra 400 plus analyzer. Fibrinogen was determined by the Claus method.

Statistical processing of the results was performed using Microsoft Exel and Statistica 6.0 by statistical analysis method by Student's t-criterion determination, data are displayed as $\mathrm{M} \pm \mathrm{SD}$, where $\mathrm{M}$ is the arithmetic average, $\mathrm{SD}$ is the average deviation, the difference between the groups was considered significant at $p<0.05$. The correlation between the various factors was estimated using the Spearman rank correlation coefficient. The difference between the groups was considered significant at $\mathrm{p}<0.05$.

\section{RESULTS}

By the results of the research among the risk factors for the emergence of coronary heart disease in patients with unstable angina we found: hypertension, dyslipidemia, 
hypodynamia, overweight, obesity, smoking, psycho-emotional factors (Table I). Many patients had a combination of several risk factors, which in turn contributes to the progression of angina. The clinical characteristics of patients are presented in the table (Table II).

By the analysis of the data from patients with unstable angina, was revealed disorders of lipid metabolism. In patients with unstable angina, compared with indicators in the control group (Table III), was revealed an increase in total cholesterol, triglycerides, low-density lipoprotein cholesterol, very low-density lipoprotein cholesterol, atherogenic ratio, before treatment.

Thus, the level of total cholesterol of patients exceeded the value of the control group by $26.2 \%(\mathrm{p}<0.01)$. Triglyceride level significantly exceeded the control figures by $50.1 \%(\mathrm{p}<0.01)$. The level of LDLC in patients significantly exceeded the indicators of the control group by $37.2 \%$ $(\mathrm{p}<0.01)$, accordingly, QCCVLDL - by $50.8 \%(\mathrm{p}<0.01)$. The coefficient of atherogenicity significantly exceeded the control value by $52.5 \%(\mathrm{p}<0.01)$. HDLC in patients was lower compared to the control group. Herewith, HDLC level in patients with unstable angina before treatment less than $1.8 \mathrm{mmol} / \mathrm{l}$ (target value for very high-risk patients) was not detected in any patient.

At the analysis of inflammatory markers there was observed their increase compared with the control group (Table IV). In patients with unstable angina pectoris CRP in blood serum significantly exceeded the value of the control group 2.5 times $(p<0.01)$. Fibrinogen in patients with unstable angina significantly exceeded the value of the control group 1.6 times. Cytokines of the early acute-phase IL- $1 \beta$ reaction in the serum of patients with unstable angina on entry to hospital significantly exceeded the levels of the control group 1.8 times $(\mathrm{p}<0.01), \mathrm{IL}-6$, as an indicator of late acute-phase reaction, in serum significantly exceeds the levels of the control group in 2 times $(p<0,01)$. Increase of cytokines levels can be considered as a factor that shows the severity of the disease. Interleukin-17 exceeded indicators of the control group by 1.8 times $(p<0.01)$. Tumor- $\alpha$ necrosis factor exceeded indicators of the control group by 2.2 times $(\mathrm{p}<0.01)$.

In the analysis of the relationship of blood lipid spectrum with markers of inflammation in patients with unstable angina was revealed the following correlative relationships: direct relationship of average power between STC and CRP ( $\mathrm{r}=0.51, \mathrm{p} 0.05)$; positive relationship of average strength between STC and IL- $1 \beta$ $(r=0,42, p<0,05)$; direct relationship of average strength between STC and IL-6 $(r=0,44, p<0,05)$; positive relationship of weak strength between STC and IL-17 ( $r=0,16$, $\mathrm{p}>0,05)$; positive relationship of weak strength between STC and TNF- $\alpha(r=0,19, p<0,05)$; positive relationship of moderate strength between STC and fibrinogen $(\mathrm{r}=$ $0.42, \mathrm{p}<0.05)$; direct relationship of moderate strength between LDLC and CRP $(r=0,40, p<0,05)$; positive relationship of moderate strength between LDLC and IL-6 CRP ( $r=0.35$, p0.05); direct moderate relationship between LDLC and TNF- $\alpha(r=0,36, p<0,05)$; positive re- lationship of moderate strength between LDLC and IL- $1 \beta$ $(\mathrm{r}=0.33, \mathrm{p}<0.05)$; positive relationship of low strength between LDLC and fibrinogen $(r=0.26, p<0.05)$. The presence of correlational relationships between blood lipid spectrum and inflammation indicators points at their role and involvement in the pathogenesis of unstable angina, and may be a prognostically important factor in coronary heart disease.

\section{DISCUSSION}

The study of inflammatory markers is extremely topical for clinical practice, since they are necessary to confirm atherosclerosis or other related pathological conditions of the body: forecasting of the states, that precede serious complications (unstable angina, myocardial infarction), assessment of coronary atherosclerosis, its progression or regression. In our research we discovered a significant increase of proinflammatory cytokines: IL- $1 \beta$, IL- 6 , IL17, TNF- $\alpha$ and CRP, fibrinogen in the serum of patients with unstable angina to compare with control group. Our results reveal the activation of local and the development of systemic inflammatory process in patients with unstable angina.

Our results are comparative to the results of other authors. Therefore, Hashmi S. In his study observed an increase in proinflammatory cytokines (IL-17, IL-6, IL-8) and heatsensitive CRP and reduction of proinflammatory interleukin-10 of patients with unstable angina and acute myocardial infarction [22]. In another study, patients with coronary heart disease was noticed an increase in TNF- $\alpha$, IL-6, and CRP to compare with a group of volunteers. In the same study, was explored the effect of excess TNF- $\alpha$ on monocytes in the blood and concluded the effect of TNF- $\alpha$ excess on monocytes in the blood was studied and there had been concluded that its excess is the main trigger mechanism to development of atherosclerosis and coronary heart disease [23]. In the experimental studies was shown that TNF- $\alpha$, a proinflammatory cytokine, is involved in destabilizing the atherosclerotic plaque [24].

So, the research of inflammation in the pathogenesis of unstable angina, ischemic heart disease is important as it gives an understanding of the course of inflammatory processes in the body. It would be interesting to make study these indicators during the course of the disease; during treatment with medicines; the effect of drugs on the level of inflammation.

\section{CONCLUSIONS}

In patients with unstable angina was revealed a significant increase in serum levels of proinflammatory cytokines: interleukin- $1 \beta$, interleukin- 6 , interleukin-17, TNF- $\alpha$ and $\mathrm{C}$-reactive protein, fibrinogen, which reveals the activation of the inflammatory process. There was revealed a significant disturbance of blood lipid spectrum in patients with unstable angina. For its correction should be recommended diet and hypolipidemic medications. 


\section{REFERENCES}

1. KarrS. Epidemiology and management of hyperlipidemia. Am. J. Manag. Care. 2017;23(9)9:139-148.

2. Townsend N, Nichols M, Scarborough P et al. Cardiovascular disease in Europe: epidemiological update 2015. Eur Heart J. 2015;36:2696-2705.

3. Kasprzyk M, Wudarczyk B, Czyz R et al. Ischemic heart disease definition, epidemiology, pathogenesis, risk factors and treatment. Post N Med. 2018;XXXI(6):358-360.

4. Balla C, Pavasini R, Ferrari R. Treatment of Angina: Where Are We? Cardiology. 2018;140:52-67.

5. Kovalenko V.M., Dorogoi A.P. Sercevo-sudynni khvooby: medico-socialne znachennia ta stratehiia rozvytcu cardiologii v Ukraini [Cardivascular disease: medical and social value and strategy of cardiology in Ukraine]. Ukrainian Cardiology Journal. 2016;3:5-14. (in Ukrainian).

6. Gandzyuk V.A. Analiz zachvoriuvanosti na ishemichnu khvorobu sercia v Ukraini [Analysis of ischemic heart disease morbidity in Ukraine]. Ukrainian Cardiology Journal. 2014;3:45-52. (in Ukrainian).

7. Waller B.F. Nonatherosclerotic coronary heart disease. The Heart / S.W. Hurst, ed. New York: McGraw-Hill; 1994, p. 1239-1261.

8. Rishko M.V.. Kucyn 0.0. Osoblyvosti ishemichnoi chvoroby serciav hirskych umovach: poshyrenist factoriv rysyku, osoblyvosti adaptacii, zachvoriuvanist a smertnist [Features of coronary heart disease in mountainous conditions: prevalence of risk factors, features of adaptation, morbidity and mortality]. Ukrainian Cardiology Journal. 2013;2:113-123. (in Ukrainian).

9. Husain K, Hernandez W et al. Inflammation, oxidative stress and renin angiotensin system in atherosclerosis. World J. Biol. Chem. 2015;6:209-217.

10. The Task Force on the management of stable coronary artery disease of the European Society of Cardiology. 2013 ESC guidelines on the management of stable coronary artery disease. Eur. Heart J. 2013;34:2949-3003.

11. AHA/ACC Guideline for the Management of Patients With Non-STElevation Acute Coronary Syndromes A Report of the American College of Cardiology. American Heart Association Task Force on Practice Guildnes. Circulation. 2014;130:e344-e426.

12. Stary HC. Natural history and histological classification of atherosclerotic lesions: An update. Arterioscler. Thromb. Vasc. Biol. 2000;20:1177-1178.

13. Tousoulis D, Oikonomou E, Economou EK et al. Inflammatory cytokines in atherosclerosis: currenttherapeuticapproaches. Eur. HeartJ.2016;37:1723-1732.

14. Braunwald E. Unstable Angina and Non-ST Elevation Myocardial Infarction. American journal of respiratoty and critical care medicine. 2012;185:924-932.

15. Ajhambetova A.0. Ateroskleros i vospalenie. Obzor literatury [Atherogenesis and inflammation. Literature review]. Science and Health. 2016;1:24-39.

16. Libby PA. Current concepts of the pathogenesis of the acute coronary syndromes. Circulation. 2001;104:365-372.

17. Liu Z, Zhang M et al. Serum CD121a (Interleukin 1 Receptor, Type I): A Potential Novel Inflammatory Marker for Coronary Heart Disease. Plos One. 2015;10:e0131086.

18. Morton AC, Rothman AM. The effect of interleukin-1 receptor antagonist therapy on markers of inflammation in non-ST elevation acute coronary syndromes: the MRC-ILA Heart Study. Eur Heart J. 2015;36(6):377-384.

19. Pantsulaia I, lobadze $M$ et al. Lipid profile and cytokines interactions during successful aging. Georgian Med News. 2015;243: 46-51.

20. Paoletti R, Gotto AM, Hajjar DP. Inflammation in atherosclerosis and implications for therapy. Circulation. 2004;109(III):20-26.
21. Lee KW, Hill JS et al. Relative value of multiple plasma biomarkers as risk factors for coronary artery disease and death in an angiography cohort. CMAJ. 2006;174 (4):461-466.

22. Hashmi S, Zeng QT. Role of interleukin-17 and interleukin-17-induced cytokines interleukin-6 and interleukin- 8 in unstable coronary artery disease. Coron Artery Dis. 2006;17(8):699-706.

23. Zhu M, Lei L, Zhu Z et al. Excess TNF-a in the blood activates monocytes with the potential to directly form cholesteryl ester-laden cells. Acta Biochimica et Biophysica Sinica. 2015;47(11):899-907.

24. Saren P, Welgus HG, Kovanen PT. TNF-and IL-1 selectively induce expression of $92-\mathrm{kDa}$ gelatinase by human macrophages. J Immunol. 1996;157:4159-4165.

\section{Scientific research work data.}

The article is a fragment of research works of the Department of Family Medicine of the Department of Postgraduate Education of Danil Halytsky Lviv National Medical University "Features of mechanisms of development and clinical course of acute and chronic forms of coronary heart disease depending on risk factors" 100101010124 (01/2014) and "Influence of risk factors and invasive treatment methods on acute and chronic forms of coronary heart disease"

\section{ORCID and contributionship:}

Yevheniia H. Zaremba - 0000-0003-1358-0182 A, E, F

Olha V. Smaliukh - 0000-0002-3153-2013 A, B, C, D

Olena V. Zaremba-Fedchyshyn - 0000-0002-4984-578X ${ }^{B}$

Olha V. Zaremba - 0000-0002-3691-2998 ${ }^{B}$

Andriy S. Kost - 0000-0001-7401-7460 B, E

Lyubov Ye. Lapovets - 0000-0001-7933-3948 A, E, F

Zoriana V. Tomkiv - 0000-0003-4030-7800 D

Oksana M. Holyk - 0000-0002-8796-996X ${ }^{D}$

\section{Conflict of interest:}

The Authors declare no conflict of interest:

\section{CORRESPONDING AUTHOR}

\section{Yevheniia H. Zaremba}

Department of Family Medicine, Faculty of Postgraduate Education, Danylo Halytskyi National Medical University Str. Pekarska 69, 79010, Lviv, Ukraine e-mail:Acad.zaremba@gmail.com

Received: 17.01 .2020

Accepted: 05.03 .2020

A - Work concept and design, B - Data collection and analysis, C - Responsibility for statistical analysis, $\mathbf{D}$-Writing the article, $\mathbf{E}-$ Critical review, $\mathbf{F}$ - Final approval of the article 